\title{
Response to Pauli, N., L. K. Abbott, S. Negrete-Yankelevich, and P. Andrés. 2016. Farmers' knowledge and use of soil fauna in agriculture: a worldwide review
}

Lisa A. Lobry de Bruyn ${ }^{1}$

Key Words: capacity; extension; soil fauna; soil knowledge

Pauli et al. (2016) captures the level of interest of the scientific community in a cross-disciplinary area of soil science and social science, and summarizes the efforts of researchers who have attempted to capture farmers' understanding of soil fauna and their practice in using soil fauna in agriculture. Not all the papers had the same overarching goal, but a number (at least a third) were focused on detailed farmers' observations on soil fauna for agricultural decisions. In my work (Lobry de Bruyn and Abbey 2003), it was critical to take an approach when interviewing farmers that we were not "testing" their knowledge of soil fauna but documenting their understanding, and how that influenced their practice (praxis). Pauli et al. (2016) did not provide a rationale for the examples they chose to use in their paper, with the specific methodology and findings of many of the case study papers not fully critiqued. This paper could have also examined the techniques used to gain farmers' knowledge of soil fauna and examine the strengths and weaknesses of the approaches. Hence, this type of reporting tended to leave the reader with a level of uncertainty as to the weight of evidence behind any particular argument or the other. One such example demonstrates "the chicken or the egg" causality dilemma as to who influences who, with the work of Pincus (2015) showing that it was only after attending a training session on soil testing that earthworms were considered important and prior to that farmers were generally unaware of their value. This example was meant to illustrate how earthworms provide a "potentially rich talking point around which to build knowledge interchange between farmers and researchers." However, the example used seems to be demonstrating a one-way information exchange process, without appreciating what farmers understand about soil fauna in agriculture. Also, with the Western Australia Wheatbelt study it would have been interesting to share with the reader the types of questions farmers were asking, and how the measurement of mycorrhizal fungi answered those questions. Again, were the researchers filling the learning needs originating from farmers or were the workshop's participants part of a research agenda? The 60 case studies presented in the Appendix were briefly described, but another value of this paper would have been to link the case studies to Table 1, in the paper, so that the coding of each paper to primary research motivation and broad theme could be crossreferenced, thereby showing where farmer knowledge was strong in certain fields of enquiry. The papers represented research up to 2015 , but did not expand on how far back the literature search went; however, with only 8 of the 60 case studies pre- 2000 it either suggests there has been a growing research interest into examining farmers' understanding of soil fauna in agriculture or difficulty in finding refereed journal papers pre-2000. Some explanation of this aspect of the work would have been useful to examine the temporal shift in research focus.

The paper did touch on the "niche existence" of soil biology as a field of research, but it could have explored the attitude that I have often observed whereby other soil scientists view soil biology as a black box, and that we do not need to know what soil fauna do in the soil, and that if conditions in the soil are "optimal," i.e., soil organisms are fed, watered, and left largely undisturbed by tillage, they will take care of themselves. My research was one of two studies undertaken in Australia used in this paper (Lobry de Bruyn and Abbey 2003). The scientists' view of soil fauna, in some respects, is mirrored by farmers who identified the presence of earthworms with a healthy soil, but had no firm opinion on how many earthworms would indicate the level of soil health (Table 1). Many farmers defined soil health as a soil that is alive, and as one farmer stated, "Soil to me is a living thing. It's not just a bit of dirt." The relative importance of soil life to other indicators used by farmers to identify a healthy soil was ranked sixth, after plant growth, soil feel, soil erosion, organic matter, weeds, and plant roots (Lobry de Bruyn and Abbey 2003). Also farmers appreciated the negative impact of their agricultural practices such as cultivation $(30 \%, \mathrm{n}=75$ farmers) and application of anhydrous nitrogen fertilizer $(5 \%, \mathrm{n}=75$ farmers) on earthworm abundance. Farmers were less inclined to mention the functions performed by earthworms in the soil $(18 \%, \mathrm{n}=75$ farmers) of breaking down stubble residue (Table 1). Most farmers viewed the role of earthworms as creating holes in the soil for water infiltration, and decomposing and burying plant material. Farmers mainly observed earthworm activity while undertaking farming activities, such as cultivation $(14 \%, \mathrm{n}=75$ farmers), but did not directly seek to examine soil fauna activity in relation to soil condition or the impact of their farming practices on soil.

In the mid-1990s a survey of Australian researchers who were studying soil macrofauna and who were asked to comment on their value as bioindicators of soil health showed that the researchers were divided in their opinion (Lobry de Bruyn 1997). Some researchers actively promoted earthworms as indicators of soil health, whereas others were reluctant to accept soil macrofauna in general as soil health indicators. For those researchers who voiced their reluctance, it was based on the difficulty of interpreting 
Table 1. Farmers' understanding of earthworms and their role in soil health identification and soil function

\begin{tabular}{|c|c|c|}
\hline Theme & Farmer quotes & $\begin{array}{l}\text { Percentage of those } \\
\text { interviewed } \\
(\mathrm{n}=75)\end{array}$ \\
\hline Soil health identification & $\begin{array}{l}\text { "Worms are a sign of fertility"; "Worms are a true sign of a healthy } \\
\text { and fertile soil type" }\end{array}$ & 86 \\
\hline Soil function & $\begin{array}{l}\text { "Worms ... break down stubble"; "The earthworms are there churning } \\
\text { it [humus] around and incorporating it" }\end{array}$ & 18 \\
\hline Effect of cultivation & $\begin{array}{l}\text { "With the zero till they [earthworms] are starting to come back"; } \\
\text { "You'll get earthworms if you don't cultivate"; "Constant cultivation } \\
\text { you kill them [earthworms] off" }\end{array}$ & 30 \\
\hline Effect of chemicals & "Detrimental thing to earthworms is ... chemicals" & 5 \\
\hline Visual monitoring & $\begin{array}{l}\text { "We don't physically go out and dig looking for them [earthworms""; } \\
\text { "Working it [soil] you can see the earthworms coming up" }\end{array}$ & 14 \\
\hline
\end{tabular}

biological data in relation to soil health, because at that point, there were few studies that demonstrated the links between soil macrofauna activity and soil health status (Lobry de Bruyn 1997). This research problem was further compounded by the inherent difficulty in studying soil biota, inadequate experimental design, and lack of long-term commitment to fund such research. The research capacity deficiencies highlighted in the 1997 paper have continued to this day, and are further stymied by the loss of experiential knowledge of farmers, which as Pauli et al. (2016) point out has been "rarely deliberately or deeply consulted." The same can be said of farmers' soil testing practice, which if we understood more about it could be harnessed for closer monitoring of soil condition and early detection of soil health problems such as soil acidification or nutrient loss. Despite recurrent language, in policy and other documents, suggesting farmers' monitoring of soil health is necessary to guide decision making and land management practices, in an examination of two decades of national-level statistics from Australia and United States we found that the reality of farmers' practice was difficult to establish (Lobry de Bruyn and Andrews 2016). It appears that we have assumed what motivates farmers to test soil but have not asked them, as Pauli et al. (2016) also noted with farmers' knowledge and use of soil fauna in agriculture.

The paper points to the loss of experiential knowledge as farmers rely on technological fixes for yield decline or migrate out of rural areas, but there is also increasing evidence, especially in highincome countries, that the farming community is getting older, with poor succession planning as well as fewer farms, meaning fewer farmers and greater areas of land to manage. There has also been a loss of communication avenues, with governments downsizing their activities and assuming that information available online is sufficient and can replace face-to-face communication and events where farmers can learn from each other and others. This paper highlights the lack of nexus between corpus and praxis as well as the deficiencies in monitoring and evaluating current and past extension activities and farmer-led activities to examine their impact, but does little to explain how these deficiencies can be addressed. The loss of joint learning opportunities through poor documentation and reflective practice needs to be highlighted further. In addition, it is important to assess what can be done to close the gap between the scientific and farming communities to avoid the narrative being a binary one between those who are the knowledge generators and those who put the knowledge into practice. Support for this approach is alluded to in the paper as "no particular type of knowledge is privileged as superior" and with the qualification of "properly applied, this knowledge will help deliver ... management toolkits that are locally appropriate and tailored to farmers' needs."

In conclusion, more discussion needs to be about the interchange between "know why" and "know how" and the mechanisms required to deliver "improved extension programs and management tool kits" that truly incorporate "how farmers value and perceive soil biota in agricultural production and sustainable land management," especially if soil scientists largely ignore soil biology and farmers' interest in soil biology. Surely, improved extension programs also rely on improved scientific practice, ensuring that scientists value farmers' knowledge and soil fauna, too, and are willing to study them.

Responses to this article can be read online at: http://www.ecologyandsociety.org/issues/responses. $\mathrm{php} / 8850$

\section{LITERATURE CITED}

Lobry de Bruyn, L. A. 1997. The status of soil macrofauna as indicators of soil health to monitor the sustainability of Australian agricultural soils. Ecological Economics 23:167-178. http://dx.doi.org/10.1016/S0921-8009(97)00052-9

Lobry de Bruyn, L. A., and J. A. Abbey. 2003. Characterisation of farmers' soil sense and the implications for on-farm monitoring of soil health. Australian Journal of Experimental Agriculture 43:285-305. http://dx.doi.org/10.1071/EA00176

Lobry de Bruyn, L. A., and S. S. Andrews. 2016. Are Australian and United States farmers using soil information for soil health management? Sustainability 8:304. [online] URL: http://www. mdpi.com/2071-1050/8/4/304 
Pauli, N., L. K. Abbott, S. Negrete-Yankelevich, and P. Andrés. 2016. Farmers' knowledge and use of soil fauna in agriculture: a worldwide review. Ecology and Society 21(3):19. http://dx.doi. org/10.5751/ES-08597-210319

Pincus, L. M. 2015. Increasing indigenous vegetable yield and nutritional quality through traditionally- and scientificallyinformed soil fertility management. Dissertation. University of California Davis, Davis, California, USA. 